\title{
ІСТОРИЧНІ ТРАНСФОРМАЦІЇ ХУДОЖНЬОГО ТЕКСТИЛЮ У КЛЮЧІ СУЧАСНОГО КОНЦЕПТУАЛЬНОГО МИСТЕЦТВА
}

\author{
Журавель-Змсєва Л. С.
}

\section{ВСТУП}

Художній текстиль як самостійне мистецьке явище на теренах України існує вже кілька десятків років. Перші мистецтвознавчі публікації, присвячені суто текстильному мистецтву, виникають ще в 1920-1930-х pр., дотепер чимало науковців працюють за цим напрямом. Протягом цього часу значну кількість трансформацій і видозмін було привнесено митцями як у технології виготовлення виробів, так і в методи сприйняття творів.

Художній текстиль традиційно був невід'ємною складовою частиною декоративно-прикладного мистецтва, тобто народним ремеслом. Уся цінність такого текстилю полягала в народних традиціях: у техніках ткацтва, символізмі й обрядовості орнаментики, варіантів сировини та колірної гами і безпосередньо в особливостях ужиткового застосування. Значення в оцінці народного виробу мали регіональна приналежність, якість виконання, слідування чи, навпаки, перетворення характерних технік (ткацтва, крою, вишивки тощо), кольорів та візерунків. Авторство ж переважно залишалося поза увагою. Активно розвивалося текстильне ужиткове мистецтво в ремісничих осередках: м. Кролевець, м. Богуслав, м. Косів (ткацтво); с. Дигтярі, м. Решетилівка, с. Великі Сороченці (ткацтво, вишивка); с. Яворів (ліжникарство) та багато інших. Такі майстерні створювалися в кожному регіоні, працювали на потреби суспільства та водночас ставали показниками традиційних особливостей конкретної місцевості.

3 настанням радянських часів починається масове виробництво текстилю. Відповідно художня якість змінюється, деякою мірою й знижується. Великі виробництва починають використовувати складні ткацькі верстати та техніки. Тут уже не мають на меті показати особливості регіону, тому художники, що працюють на заводах та фабриках, адаптують і уніфікують традиційні мотиви, поєднують їх із найбільш економічно вигідними ткацькими підходами, залучають різноманітну сировину, розширюють спектр кольорів. Продукція, що виготовляється на великих виробництвах, стає масовою та безадресною. Багатотиражність усуває ручну працю, залишається лише далекий відгомін від традиційної текстильної цінності. Однак десь за цих часів зароджуються нові тенденції галузі - текстильний дизайн. 
3 появою текстильного виробництва відокремлюються від мирського (побутового) текстилю митці, що вкладають у текстиль ідею та творчість, стають художниками окремого жанру. Нитка та іiі мінливі м'які властивості стають джерелом натхнення та способом самовираження. Художній текстиль спочатку у формах традиційного народного ткацтва починає передавати авторські думки, а згодом i породжувати все нові та нові методи, залучати нехарактерні матеріали, виходити за межу двовимірності, трансформуватися. Текстиль стає виразним матеріалом концептуального мистецтва.

В Україні, як і по всьому світі, пластичні якості текстилю високо цінуються митцями, що засвідчують численні виставки. Регулярні всеукраїнські виставкові проєкти «Трієнале художнього текстилю», «Текстильний шал», «Текстилізм», «Мінітекстиль», великий виставковий проєкт Міжнародний бієнале художнього текстилю «Скіфія» та багато інших демонструють, що сьогодні художній текстиль як мінливе, чуттєве та тепле мистецтво різко реагує на світові проблеми чи тенденції, $є$ самостійним жанром, що перебуває в постійному пошуку нових форм, стає мінімальним чи максимальним проявом ідеї автора.

Сучасне текстильне мистецтво вже давно вийшло за межі традиційних ткацьких технік, віднайшло нові, всотало сучасні матеріали, трансформувало сталі поняття та шаблонні уявлення. Художній текстиль нині відповідає умовам світової унітарності й ідейній перевазі концептуального мистецтва і став експериментальним.

\section{1. Етапи розвитку традиційного та радянського текстилю}

Традиційний текстиль нерозривно пов'язаний із народною культурою. Більшість вітчизняних мистецьких досліджень щодо аспектів вивчення народного текстилю так чи інакше пов'язані 3 фольклористикою, етнографією. Тканини зазвичай вивчаються на рівні з іншими видами декоративно-прикладного мистецтва і значно рідше стають предметом окремого дослідження. Так, наприклад, у праці доктора М. Селівачова «Лексикон української орнаментики» ${ }^{1}$ розгляд традиційного текстилю посідає окреме місце поряд з іншими промислами.

Народний текстиль представлений побутовими й обрядовими тканинами й одягом, що значно різнилися залежно від регіону. Змінювалися колірна гама, техніки такання та вишивки, орнаменти та їх розташування, крій одягу тощо. Осягнути весь спектр змін щодо текстилю в різних регіонах можна, якщо ознайомитися зі змістовним виданням Свгена Шевченка «Українська народна тканина» (1999р.). Книга являє собою вичерпний словник технік ткацтва та вишивки, матеріалів та видів тканин, що вироблялися на території України².

${ }_{1}^{1}$ Селівачов М. Лексикон української орнаментики. Київ : Редакція вісника «Ант», 2005. 400 с.

${ }^{2}$ Шевченко С. Українська народна тканина. Київ : Артанія, 1999. 416 с. 
Найбільш поширеними ручними видами ткацтва $\epsilon$ верстатне та килимове. Методом верстатного ткацтва виготовлялися тонкі тканини як простих переплетень: полотно, саржа, комбіновані, рогожка, ажурні, атласно-сатинові; так і складніших, як-от перебірні, чорно-білі, поперечносмугасті; а також вибагливих, як-от плахтові чи стрічкові. Широко висвітлено всі види верстатного ткацтва та різновиди технік килимарства в альбомі-посібнику Сергія Нечипоренка «Декоративні тканини та килими України» $(2005 \text { р. })^{3}$.

Знавцем народного текстилю України можна вважати Олену Никорак, яка $\epsilon$ автором багатьох публікацій із цієї тематики («Українська народна тканина XIX-XX ст.: типологія, локалізація, художні особливості» $(2004 \text { р. })^{4}$, «Українська народна тканина XIX-XX ст.: типологія, локалізація, художні особливості. Інтер'єрні тканини» (2007р.) $)^{5}$ тощо). У своїх дослідженнях О. Никорак розкриває історичний розвиток художньої тканини, чітко формує типологію виробів за принципом їх застосування (побутові, одягові, обрядові й інші). Авторка звертає особливу увагу на інтер'єрні тканини, їхню обрядовість, чим підкреслює нерозривний зв'язок народного мистецтва 3 етнографією та фольклором. Авторка зосереджує увагу на західних регіонах XIX-XX ст., де ткацтво набуло власної характерності та яскравості. Як і С. Нечипоренко, О. Никорак робить детальний огляд та знайомить читача 3 ремізним ткацтвом та видами побутових тканинах, їх застосуванням в інтер'єрах.

Окрему мову можна вести про народне килимарство. Сама лише кількість методів ткацтва дає широкий спектр варіативності зображень, що, безумовно, позначається на візерунковому та тематичному розмаїтті виробів. Так, найбільш популярними килимовими техніками $є$ «у вічко», «на косу/межову нитку», «дірчаста на пряму/на косу», «кругляння», «ворсове (вузликове) ткання», «закладне», «скосами». Більшість виробів народного килимарства розподіляють за виглядом зображення: геометричні та рослинні. Західним регіонам більш властиві геометричні візерунки, центральним та східним - рослинні мотиви. Залежно від характеру зображення використовується та чи інша техніка ткання. Цікаво, що під час створення килима майстрині рідко робили попередній картон, заздалегідь знали, як буде виглядати закінчений виріб. Так, вирізняються барвистістю, яскравістю кольорів та застосуванням великих квіткових форм полтавські килими. Західним територіям притаманний окремий вид геометричних килимів, покривал iз натуральної вовни - ліжників.

\footnotetext{
${ }^{3}$ Нечипоренко С. Декоративні тканини та килими України : альбом-посібник. Київ, 2005. 432 с.

${ }^{4}$ Никорак О. Українська народна країна XIX-XX ст.: типологія, локалізація, художні особливості. Львів, 2004. $583 \mathrm{c}$.

5 Никорак О. Українська народна тканина XIX-XX ст.: типологія, локалізація, художні особливості. Інтер'єрні тканини (за матеріалами західних областей) : дис. ... докт. мистецвозн.: 17.00.06. Львів, 2007. 583 с.
} 
Художнє ткацтво як складова частина народного мистецтва відзначається високим рівнем майстерного виконання та водночас непрофесійністю зображень. Відсутність у майстрів народного декоративно-прикладного мистецтва фахової академічної мистецької освіти виявляється в наївності сюжетів, простоті композиції, іноді навіть в іiі порушенні, у невибагливості форм та подекуди незбалансованості кольорів чи пропорцій. Саме таке, особистісне, бачення майстра, у рамках традиції, є родзинкою цінності народного мистецтва. Особливо яскраво це позначається на виробах з народних текстильних осередків. Формування мануфактур сприяло і підвищенню фаховості майстрів i посиленню місцевих художніх ознак. Виготовлення тканин зосереджується в конкретних містах та селах, серед яких найбільшими є м. Кролевець (Сумська обл.), м. Косів (Івано-Франківська обл.), м. Решетилівка (Полтавська обл.), с. Великі Сороченці (Полтавська обл.), м. Богуслав (Київська обл.), с. Обуховичі (Київська обл.), с. Яворів (Закарпатська обл.), с. Сунки (Черкаська обл.), с. Дігтярі (Чернігівська обл.), міста Львів, Київ, Черкаси, Луцьк та інші. Згодом саме такі художні осередки стали основою для формування потужних художньопромислових фабрик із використанням як ручної роботи, так i механізації деяких допоміжних технічних процесів.

Цехи об’єднували майстрів та митців. Неодноразовою практикою було запрошення до роботи в мануфактурі іноземних фахівців. Так у культуру та традицію народного мистецтва потрапляли нові підходи чи техніки, візуальні образи чи орнаментальні елементи, удосконалювалися навички робітників.

Одним із найбільш відомих осередків є м. Кролевець, де в 1902 р. було засновано технічний навчальний заклад, де вихованці опановували ази майстерності з деяких видів народних промислів. Пізніше, у 1922 р., було засновано Кролевецьку фабрику «Художнє ткацтво». Кролевецьке ткацтво вирізнялося переважно виготовленням побутових тканин щоденного й обрядового характеру. Так, в асортименті виробів переважали настільники, лавники, фіранки, найбільш ціннісними є ткані рушники. Із 2011 p. тут діє Музей Кролевецького ткацтва, де представлені як стародавні рушники XIX ст., так і сучасні ${ }^{6}$.

Ще одним визначним ткацьким осередком $\epsilon$ м. Решетилівка. Традиційне ткацтво Полтавщини представлене рослинним гладким килимарством. Особливістю даного регіону є ткацтво килимів у техніках «кругляння», «зачіпками», «на межову нитку», «зірчаста», «на косу нитку». Властиві рослинно-квіткові мотиви, образи дерева, в’юнких рослин із фантасмагоричними великими та яскравими квітками. 1905 p.

\footnotetext{
${ }^{6}$ Бажан О. Кролевець. Енизилопедія історії України / редкол. : В. Смолій та ін. Інститут історії України НАН України. Київ : Наукова думка, 2009. Т. 5. С. 407-560.
} 
офіційно датується створення текстильної майстерні, яка в 1922 p. перетворилася на промислову артіль. У 1960 р. стала фабрикою мистецьких виробів, при якій функціонувала школа майстрів. Полтавські килими вирізняються особливо масивними формами квіткових елементів, колірною гамою. Притаманні їм яскраві червоні, жовті, зелені тони, переважає тепла гама із землистими відтінками ${ }^{7}$.

Меншим промислом та не меншим за своєю значущістю є осередок с. Дігтярі. Ткацтво цієї місцевості відрізнялося особливою майстерністю виготовлення одягових тканин, насамперед для поясного одягу. Ще із середини XIX ст. відомі суконні та ткацькі промисли цього регіону (Сукновальні Галагана). У 1897 р. засновано Дігтярівську ткацьку школу-майстерню, яка готувала майстрів із виготовлення плахт. Школамайстерня мала власну красильню та килимовий клас. Промислова же артіль заснована уже за радянських часів, у 1926 р. У повоєнний час, у 1961 р., артіль була переорганізована в Дігтярівську фабрику художніх виробів ім. 8-го Березня ${ }^{8}$.

Найбільш знаним і нині ткацьким осередком є м. Косів. Від 1850 p. Косів є центром ткацтва. Засноване в цей час австрійського панування ткацьке товариство активно сприяло розвитку ремісництва. У 1882 p. товариство засновує ткацьку школу. Найбільшого поширення набули ткацтво та вишивка. Знаковими для Косівщини вважаються узорні тканини: ткані верети 3 поперечними смугами, покривала, пояси та крайки, особливим напрямом стає ліжникарство. У 1940-х рр. по всьому регіону створюються невеличкі текстильні артілі, зокрема і в Косові. Розповсюджені тут переважно геометричні та геометризовані мотиви, човникові, перебірні та килимові техніки. Ткацтво Косівського району завжди відрізнялося, окрім детальності та складності візерунків, ще й особливим ставленням до традиції кольору. Тут, окрім традиційних червоних, чорних та білих тонів, часто траплялися вкраплення жовтого, синього чи навіть фіолетового. Місцеві килими поступалися полтавським за вибагливістю форм та не за майстерністю їх виконання, мали власний, неповторний шарм саме західноукраїнського ткацтва ${ }^{9}$.

Отже, протягом історії, під впливом зовнішніх чинників народне традиційне ткацьке ремесло набувало різноманітних технологічних змін i трансформацій. Чимало народних осередків упорядковувалися, об'єднувалися й утворювали виробничі цехи й мануфактури. Переродження ручного ткацтва у промисловість було примусовим явищем, проте віянням часу та потребою суспільства й індустріалізації.

\footnotetext{
${ }^{7}$ Бажан О. Кролевець. Енциклопедія історії України / редкол. : В. Смолій та ін. Інститут історії України НАН України. Київ : Наукова думка, 2009. Т. 5. С. 407-560.

${ }^{8}$ Верменич Я. Дігтярі. Енциклопедія історії України / редкол. : В. Смолій та ін. Інститут історії України НАН України. Київ : Наукова думка, 2004. Т. 2. С. 399-518.

${ }_{9}$ Вербиленко Г. Косів. Енциклопедія історії України / редкол. : В. Смолій та ін. Інститут історії України НАН України. Київ : Наукова думка, 2009. Т. 5. С. 212-560.
} 
Одним із найбільш докладних дослідників промислового розвитку українського ткацтва та народних ремісничих трансформацій можна назвати Адама Жука. У таких дослідженнях, як «Український радянський килим» (1973р.), «Сучасні українські художні тканини» (1985р.), «Регіональні художньо-стильові особливості українського килима» (1985р.), автор дає огляд машинних тканин і ручних художніх тканин, характеризує килимарську традицію та іï зміни в умовах виробничого процесу. Дослідник аналізує проєкти, розробки, орнаменти та колірні рішення, сюжети радянських килимів повоєнного часу.

Короткий огляд різноманітності народного текстилю та процесів його трансформації демонструє робота Інни Яковець «Художній текстиль ручного виготовлення: історичний контекст і значення у формуванні національної складової вітчизняної української культури» $(2005 \text { р. })^{10}$. Авторка зосереджується на розгляді змін і трансформацій, що зазнавав художній текстиль під впливом зовнішніх історичних, соціальних, економічних та політичних процесів. І. Яковець змальовує умови, у яких текстиль перероджувався, визначає основні напрями руху ручного та промислового текстилю в історичній хронології.

Сьогодні ткацтво та килимарство радянської доби плідно досліджує Ольга Ямборко. Авторка переважно зосереджується на вивченні килимарства на теренах підрадянської України, умов та концепцій створення. Історичні аспекти створення та розвитку текстильних підприємств спонукають до розгляду функціонування самої системи радянського виробництва, художньої організації, місця художника та майстра у формуванні промислової продукції. Стаття «Художник декоративного мистецтва і художня промисловість у радянській системі виробничих відносин» окреслює процеси взаємодії митців та державного апарату. Ідеологічна основа Радянського Союзу мала на меті рівність, отже, і доступність, що стимулювало економіку тиражувати та поширювати загальномасовий продукт ${ }^{11}$. Активний ріст промисловості призводить до перетворення мистецьких, художніх осередків на виробництва, переходу їх на виготовлення масової продукції. Майстер, кустарний ремісник перетворюється на майстра, робітника фабрики; художник - на дизайнера, що розробляє відтворюваний рисунок. Авторське мистецтво локалізується в межах виставкових залів та музеїв, уже поодиноке декоративне та народне мистецтво - у межах творчих спілок. Отже, державні органи управління тримали всі важелі впливу на

\footnotetext{
10 Яковець I. Художній текстиль ручного виготовлення: історичний контекст і значення у формуванні національної складової вітчизняної української культури : збірник наукових праць. Інститут мистецтвознавства, фольклористики та етнології ім. М.Т. Рильського НАН України. Київ, 2008. Вип. 8. С. 216-222.

${ }_{11}$ Ямборко О. Художник декоративного мистецтва і художня промисловість у радянській системі виробничих відносин. Наукові записки. Серія «Мистецтвознавство». Тернопіль, 2018. № 2. Вип. 39. C. 253-255.
} 
мистецтво шляхом тиражувальних масових мистецьких зразків та окремих державних замовлень ${ }^{12}$.

За умов повсюдно масового продукту радянська влада диктує художні пріоритети, спонукає до коригування споживацьких потреб, формує попит. У публікації «Килим у житловому інтер'єрі як елемент радянської культури побуту» О. Ямборко простежує видозміни інтер'єрів періодів до війни та після, висвітлює асортимент і художні особливості текстильних виробів, іхній спадковий зв'язок з інтер'єрами народних жител і традиційних тканин. Так, у довоєнний час значно більше інтер'єрного текстилю було ручного виготовлення. Поряд iз виробничими (на той період і такі вироби значною мірою виготовлялися у творчих ткацьких артілях) веретами, доріжками, налавниками, рушниками, килимами та ліжниками чимало було власноруч вишитих, в’язаних, плетених тканин. У повоєнний час відбувається зміна акцентів не лише в інтер'єрах, але й в архітектурі, що має відбиток i в застосуванні більшої кількості саме тиражованих тканин, у вигляді жакардових портьєр, покривал. Килим також виступає акцентом та декоративним елементом, змінюється в розмірах та візуальному наповненні, поступається більш уніфікованим мотивам ${ }^{13}$.

Дослідниця Ольга Ямборко розглядає текстиль радянської доби, а саме килимарство, 3 позиції національної ознаки того часу. У доробку «Українське промислове килимарство як бренд у радянській системі художніх промислів» авторка акцентує увагу на національних ознаках у промисловій лінії продукції українських фабрик. Фахові українські художники працювали над перетворенням народних мотивів, удосконаленням i спрощенням колористики народних тканин, килимів. Для збільшення тиражності чимало етнічних орнаментальних елементів спрощували, дублювали, традиційні ткацькі мотиви позбавляли зайвої виразності чи детальності, локалізували кольори. Художники створювали, так би мовити, універсальний шаблон, який затверджувався керівництвом i водночас презентував цим уніфікованим образом ту чи іншу фабрику. Таким чином утворювалися впізнавані регіональні візерунки ${ }^{14}$.

Однак найбільш визначальним етапом перетворення українського народного текстилю на шляху до концептуального мистецтва можна вважати період 1930-1960-х рр., коли під впливом радянської ідеології та державної монополії замовлення i попиту українські митці постають перед завданням відновлення класичного гобелена, єднання монументального живопису 3 текстильним утіленням. Період, коли

\footnotetext{
12 Ямборко О. Художник декоративного мистецтва і художня промисловість у радянській системі виробничих відносин. Наукові записки. Серія «Мистецтвознавство». Тернопіль, 2018. № 2. Вип. 39. С. 254.

13 Ямборко О. Килим у житловому інтер'єрі як елемент радянської культури побуту. Народознавчі зошити. Львів, 2018. № 5 (143). С. 1149-1160.

14 Ямборко О. Українське промислове килимарствояк бренд у радянській системі художніх промислів. Народознавчі зошити. Львів, 2020. № 1 (151). С. 49-59.
} 
3'являється забаганка ошатно прикрашати парадні приміщення первинно урядових, пізніше просто громадських, установ килимами із сюжетними, портретними, побутовими, жанровими образами. Стилістика килимів, яка 3 подачі мистецтвознавців набула власної назви «тематичні килими» ${ }^{15}$. Здається саме таке воскресіння ідеї гобеленів XVI-XVII ст. в поєднанні живопису із ткацтвом, під тиском загальнодержавних ідей, дало поштовх подальшому трансформуванню текстильного виставкового мистецтва. Авторський текстиль, що був згрупований у межах творчих об'єднань, музеїв, виставкових залів, отримав можливість самовиразитися в сюжетах, тематиках під контролем доктрин та ідеом. 3 падінням політичної системи митці художнього текстилю під впливом економічного занепаду дезорієнтуються, як і всі, проте із часом починають відроджувати народні традиції і стимулювати розвиток того творчого напряму, що зародився в формах тематичного радянського килима. Сюжетність не обмежується, зхрещеність із монументальною манерою стимулює експериментувати надалі.

\section{2. Аспекти сучасного художнього текстилю як засобу концептуального мистецтва}

Гостро нині стоїть питання меж та напрямів у сучасному мистецтві, немало їх визначається дослідниками, немало пробудовується мистецьких течій. Найбільш цікавими працями на цьому поприщі $\epsilon$ доробки Е. Кан ${ }^{16}$, Е. Андреєвої ${ }^{17}$, Е. Бобринської ${ }^{18}$, А. Звінчук ${ }^{19}$ та багатьох інших.

Чимало дослідників сходяться в думці, що концептуалізм бере свій початок приблизно з 1960-х рр., коли в мистецтві панують різні мистецькі течії, як-от дадаїзм, мінімалізм, поп-арт, неодадаїзм, абстракціонізм тощо. Серед цього натхненного розмаїття формуються також постулати концептуалізму. Домінує ідея виродження філософії та приходу на iï місце мистецтва. А. Звінчук зазначає: «У концептуальному мистецтві найважливіший аспект твору - це ідея, або концепція. Це означає, що всі плани i рішення ухвалюються заздалегідь, а саме виконання $\epsilon$ формальністю. Ідея стає тим механізмом, який створює мистецтво». ${ }^{20}$ Отже, ця ідея нівелює ремісничий аспект мистецтвотворення, змінює актуальні до цього пріоритети, виводить фантазію поверх матеріальності.

\footnotetext{
15 Ямборко О. Український тематичний килим 1930-1960-х рр. як мистецька практика соцреалізму. Народознавчі зошити. Львів, 2019. № 1 (145). С. 57-65.

${ }^{16}$ Кан Е. В начале было слово, и слово было "contemporary art". Аpm-курсив. Інститут проблем сучасного мистецтва Національної академії мистецтв України. Київ, 2010. № 5. С. 13-16.

${ }_{17}$ Андреева Е. Постмодернизм: Искусство второй половины XX - начала XXI в. Санкт-Петербург : Азбука-классика, 2007. 493 с.

18 Бобринская Е. Концептуализм. Москва : Галарт, 1994. 245 с.

19 Звінчук А. Художня практика художнього концептуалізму. Актуальні питання культурології : альманах наукового товариства «Афіна». Рівне, 2012. Вип. 12 С. 3-6.

20 Звінчук А. Художня практика художнього концептуалізму. Актуальні питання культурології : альманах наукового товариства «Афіна». Рівне, 2012. Вип. 12 С. 3.
} 
Сучасне концептуальне мистецтво у XXI ст. подекуди доводиться до абсурду. Теорія незначущості якості твору віддається на поталу авторського задуму, що призводить до фактичного самознищення матеріального мистецтва та виведення його на рівень безтілесного філософського міркування, замикає еволюційне коло концептуалізму. Виходячи за межі матеріальності, це мистецтво 3 60-70-х рр. вийшло за рамки картин, зачало взаємодію із простором, дією, рухом, звуком. Так народилися явища інсталяції, перформансу, аудіо-арту, відео-арту тощо.

Наприкінці XX - на початку XXI ст. саме текстильна творчість стала тим засобом, що давав художнику можливість виходити за межі простору, змінювався пластично, об'єднував, комунікував, був тлом чи безпосереднім об'єктом. Художній текстиль покинув межі галузі ужитковості, набув неповторної самостійності, надав можливості, яких потребувало нове мистецьке слово. Художники без обмежень матеріалу мають абсолютну творчу свободу, завзято вдаються до пошуків і експериментів. Техніки, які вони винаходять, якими користуються, ще не написані, не завчені, не впорядковані, на відточені, не визнані. $€$ результатом власного авторського винаходу, дослідження та практики. Текстильні твори також не обмежені форматом, площиною чи конкретним матеріалом. Нитка для сучасного митця стала зв'язком не поєднуваних досі матеріалів ${ }^{21}$.

Витвори текстилю нині стали майже театральним дійством, де глядач - активний учасник, іноді і сам творець ${ }^{22}$. Для втілення задуму використовуються найрізноманітніші матеріали звично м'якої групи: нитка, вовна, пряжа, хутро, шнур, тканина; і нехарактерні: метал, дерево, целофан, кераміка, папір, пластик, поліетилен тощо ${ }^{23}$.

Актуальні проблеми світового масштабу сьогодні є тематиками творів концептуального мистецтва, а значить, і текстилю зокрема. Питання екологічних забруднень, утилізації сміття в художньому текстилі посідають особливе місце, адже саме експериментальний текстиль дає можливість привернути увагу до світової проблеми, вийти за стандартні рамки мистецтва, проявити творчий потенціал та зробити свій безпосередній внесок у переробку матеріалів, що не розкладаються. Одними 3 таких матеріалів $є$ всі види пластику, поліетилену, целофану тощо. Українські митці використанням таких матеріалів прагнуть донести також ідеї переродження народних цінностей, осучаснення традиції, так, наприклад, побудований проєкт Наталки Шимін «Трансформація», де в основі застосовується пакувальна плівка «пінобабл». Формуванням

\footnotetext{
${ }^{21}$ Кусько Г. Рух мистецтва тканини в Україні. Художній текстиль. Львівська школа : альбом / авт.-упоряд. Т. Печенюк. Львів, 1998. С. 78.

${ }_{22}$ Кусько Г. Рух мистецтва тканини в Україні. Художній текстиль. Львівська школа : альбом / авт.-упоряд. Т. Печенюк. Львів, 1998. С. 78.

${ }_{23}$ Чегусова 3., Печенюк Т. Художній текстиль як складова національно-культурного простору (про Першу та Другу всеукраїнські трієнале художнього текстилю). Студії мистещтвознавчі. Інститут мистецтвознавства, фольклористики та етнології ім. М.Т. Рильського Національної акдемії наук України. Київ, 2009. № 1 (25). С. 79-99.
} 
українських традиційних візерунків авторка доносить нові значення цих елементів, вписаних у сучасні умови та контекст ${ }^{24}$.

Використання та можливості екологічних матеріалів також $\epsilon$ сучасною вимогою світового суспільства. Український художній текстиль активно на це відгукується. Галина Дюговська - автор, що багато років використовує навички лозоплетіння, поєднує його 3 нитками. Каркасною основою іiі творів $є$ лозинні, дерев'яні або металеві прути. Так, мисткиня працює з об'ємом, простором і повітрям, робить прозоро-мереживні композиції ${ }^{25}$.

Поєднання матеріалів із метою посилення виразності без порушення просторових меж є особливістю творчості Ярослави Ткачук. Майстриня дотримується традиційних і ворсових технік ткацтва, формує текстурні перепади, оздоблює фурнітурою, використовує металеві накладки, що стають ключовими для виразності образу фрагментами композицій. На гобеленах «Як птахи», «Засватана», «Мироносиці» руки й обличчя металеві пластини. Текстурні перепади та фактуру авторка формує різноманітними плетіннями, шнурами, намистинами тощо. Колірна гама робіт дуже стримана, побудована на мінімальних відтінках, максимально наближених кольорів до невибіленого волокна, як ознака ідеї національної ідентичності та самоідентифікації, що також є особливо актуальним питанням у світі ${ }^{26}$.

Можливості виходу за рамки, комбінування непоєднуваного, усе це ріднить концептуальне мистецтво із сучасним художнім текстилем. Однак останній має ще й власну функцію - трансформувати традицію, 3 якої походить, надавати їй нового резонансного звучання. Синтез, що пропонується сучасними митцями концептуального мистецтва i представниками художнього текстилю, існує на рівні, як в українському полі, так і в усесвітньому мистецькому руслі ${ }^{27}$.

В Україні та світі митці втілюють свої ідеї в межах численних популярних стилістичних технік на зразок стрінг-арту, ассамбляжу, коллажу, аплікації, долучаються інтерпретації національних традиційних технік оздоблення тканин, типу батику або шиборі (батик вузлами). Вітчизняні художники нарівні із зарубіжними майстрами переступають край площинності ступаючи у царину об'ємно-просторових об'єктів, інсталяцій, м'якої скульптури ${ }^{28}$.

\footnotetext{
${ }^{24}$ Сліпченко К. Коди «Трансформації» : стаття. Zaxid.net. 23.11.2017. URL: https://zaxid.net/ kodi_transformatsiyi_n1442300.

${ }^{25}$ Титова Е. «Под сенью ангела» : статья. Севастопільський художній музей ім. М.П. Крошицького : вебсайт. 03.07.2013. URL: http://www.sevartmuseum.info/2013/07/podsenjuangelov.html.

26 Ярослава Ткачук : інтерв'ю. Made in Ukraine. 12.10.2010. URL: http://made-in-ukraine.info/ yaroslava-tkachuk/.

${ }^{27}$ Гончар К. Текстиль та contemporary art. Точки перетину. Художні практики початку XXI cm.: новації, тендениії, перспективи : матеріали Всеукраїнської науково-практичної конференції, м. Київ, 24 листопада 2017 р. Київ, 2017. С. 373-375.

28 Шнайдер А. Конструктивні особливості об'єктів об'ємно-просторового текстилю. Наукові записки. Візуальні мистеитва. Серія «Мистецтвознавство». Тернопіль, 2017. № 1. Вип. 36. С. 190-197. 
У взаємозв'язках українського текстильного мистецтва і світового концептуального найбільше дотичностей відслідковується у техніках колажу, ассамбляжу й аплікації. Це техніки, що дають митцям широкі можливості маніпулювати кольором та текстурою матеріалів, утворювати рельєфні перепади, включати не лише текстильні матеріали тощо. Техніка коллажу є методом роботи для таких художниць, як Elfi Cella зі Швеції, Irini Gonou із Греції, Cas Holmes із Великої Британії, Arlene Morris iз США, багатьох інших. В Україні ця техніка має не менше прихильників, серед яких Ольга Родзик, Анастасія Допервянська, Алевтина Кляповська, Тетяна Мялковська й інші.

По своїй сутності наближеною до колажу є техніка аплікації. Та все ж ій притаманна двовимірність. Переваги аплікативної техніки у фактурності матеріалів, колористичній гармонії, якої здатен досягти автор. Яскравими представниками сучасної аплікації $є$ бельгійка Ingrid van der Zalm і американці Leisa Rich i Thom Atkins. Trisha Hassler iз США особливо цікава своїми експериментами в поєднаннях текстилю та металу. Ї̈̈ аплікації поєднуються з текстурним металевим тлом. Серед українських митців у техніках квілту, аплікації й ассамбляжу працюють Наталя Лашко, Наталя Пікуш, Лариса Шейх, Юлія Тулупова, Оксана Цюпа, Ірина Шостак-Орлова, ще чимало художників. Техніка печворка (клаптове шиття) особливо цікавить таких майстринь, як: Тетяна Богачук, Тетяна Бовсуновська, Ніна Янчуковська, Наталя Сафронова. Особливо яскравим проявом концептуалізму сучасного текстилю $\epsilon$ техніка ассамбляжу, що передбачає ще більше залучення нехарактерних форм та матеріалів до текстильного твору. Ассамбляж - це свого роду гра $з$ перепадами висот і ритмів, протекція м'якої скульптури. Ця техніка характерна для творчості таких митців, як С. Берман із Росії, Marisa Ramirez iз Мексики, El Anatsui з Нігерії, в Україні ж ассамбляжем користуються Миколай Бабак, Надія Антонець та інші. Текстиль, що зазіхає на терена круглої скульптури, $є$ викликом із зони сучасного концептуального мистецтва, безумовно, і викликом з боку художнього текстилю. М'якою круглою скульптурою відомі українець Андрій Шнайдер, кореєць Un Li, бразиліанка Anne Maier, ірландка Helen O’Leary, ще багато митців по всьому світу.

Сучасною текстильною течією є стрінг-арт. «Ізонитка», «нитяний дизайн», «нитяна графіка», «зображення ниткою» - назви одного явища, ще одна значна позиція в концептуальному мистецтві сьогодення. Зображення, що створене ниткою-лінією, на полотні-стіні, пензлемцвяхом-молотком. Водночас є яскравим прикладом поєднання текстилю та металу. Метод передбачає формування образу через натягування через перепони (кнопки, шурупи, цвяхи) нитки в певному напрямку, ритміці та щільності. Цей вид творчості вельми популярний серед 
закордонних митців, як-от: Debbie Smyth з Ірландії, Pamela Campagna 3 Італії, Petros Vrellis із Греції, Israel Narváez Romero з Іспанії. В Україні ж стрінг-арт тільки набирає популярності та масовості, ним займаються Руслан Колмиков, Анна Панкова, Сергій Зелений та інші.

Великим попит сьогодні у світі мають етнічні надбання, народні техніки та практики. Серед художників зросла зацікавленість до старовинних i традиційних мистецьких технік, які вони гармонійно поєднують із новими матеріалами та методиками. До таких технік ще із середини минулого століття входить батик і всі його підвиди, народна вибійка, техніки фарбування природними барвниками. Найбільш поширене в Україні застосування технік вільного розпису, батика холодного та гарячого. Знаними українськими майстрами батика $\epsilon$ Наталя Шемякіна, Лариса Лукаш, Олена Зайченко, Інна Валітова й інші. Менш популярний у фахових митців України метод фарбування натуральних тканин Шиборі (Сіборі, або вузликовий батик). Частіше можна побачити зразки такого фарбування в дизайні інтер'єрів або в побутовому вжитку, наприклад в одязі. Проте вільні техніки батика чи розпису та Шиборі більш поширені у світі серед професійних майстрів і аматорів. Серед яких знаними $є$ Jane Callender iз Великої Британії, Joanna Fowles 3 Австралії, Suzanne Connors iз США, Momiji studio 3 Канади. Техніка Шиборі проявляється в сучасному мистецтві дуже мінливою та дивовижно експериментальною. Утворення великої кількості згинів, прошивань, закрутів, обмотувань, защипів, зажимів, барвників різного походження (природні чи штучні) - усе це робить техніку широко варіативною. Експериментальність фарбування полягає також у використанні рослин та іржавих металів. Широкий спектр можливостей розписів та методів фарбування розкривають іноземні автори в публікаціях (Janice Gunner "Shibori",29, "Shibori for textile artists" Heppard "Wathercolor batik. An artist's guide to watercolor batik on rice paper"32 тощо).

Значною мірою українське текстильне мистецтво розвивається у злагоді зі світовими тенденціями, не вступає з ними в конфронтацію, вливається в загальну ритміку концептуальності. Експериментальні проєкти в мистецькому просторі України з'являються нині значно частіше та відрізняються не меншою прогресивністю задумів, жвавістю й інтерактивністю, ніж світові. Численні виставкові заходи як локального, так і міжнародного масштабу є вже звичними на теренах

\footnotetext{
${ }^{29}$ Gunner Janice. Shibori. Batsford, 2006. 127 p.

${ }^{30}$ Gunner Janice. Shibori for textile artists. Kodansha International, 2007. 127 p.

${ }^{31}$ Southan. Mandy. Shibori: Designs and Technique. Search, 2008. 96 p.

${ }^{32}$ Martha C.S. Heppard. Wathercolor batik. An artist's guide to watercolor batik on rice paper. Xlibris Corporation, 2015. $84 \mathrm{p}$. 
України, демонструють готовність вітчизняного мистецтва до загальносвітових інтеграційних процесів.

Активний розвиток виставкової діяльності в галузі художнього текстилю незалежної України датується 1990-ми рр., коли відроджувалися покинуті із занепадом промисловості й економічним проваллям текстильні традиції, мистецькі осередки, творчі об'єднання. Організація, проведення громадських заходів для популяризації мистецтва текстилю, влиття творчого руху у світові віяння, заохочення до виставкової діяльності майстрів - нагальні проблеми того часу.

Так, найбільш визначальними подіями були програма підтримки народного килимарства «Екологічний ракурс» 3. Шульги, 3. Семак i В. Гуменюк, культурні заходи «Сучасний текстиль і традиції» та інші, що мали загальносуспільний характер. Проєкти включали семінари, лекторії, теоретичні практикуми, наукові конференції, всеукраїнські та міжнародні виставки, майстер-класи, пленери. За умов посиленої уваги до ткацтва виникає симпозіум художнього текстилю в місті Херсоні, що покликаний був поставити на один щабель роботи українських художників та іноземних фахівців. Подія стала резонансною. Автори, серед яких і зараз Людмила Єгорова й Андрій Шнайдер, продовжили проєкт, зробили його Міжнародним бієнале художнього текстилю «Скіфія». Бієнале включає групові творчі акції, перформанси, персональні події: творчі вечори, круглі столи, індивідуальні виставки.

У 1996 р. відбувся Перший міжнародний симпозіум художнього текстилю «Скіфія», у якому взяли участь представники Свропейської текстильної асоціації. Первинною ідеєю цього симпозіуму стало застосування інновацій, пошук нових методик і експеримент у царині художнього текстилю, свобода самовираження можливостями текстилю, фактично інтеграція м'якого мистецтва в концептуалізм. Автори не обмежували учасників жодними рамками, заборонами на використання тих чи інших матеріалів, форм, об'ємів, технік чи тематик. У творах бієнале можна побачити використання традиційних технік ручного та човникового ткацтва, батика, вільного розпису, валяння, вибійки, плетіння, ассамбляжу, аплікації, квілту, шиття, вишивки та безліч авторських неповторних знахідок. Застосування різноманітних матеріалів, як-от нитка, тканина, текстильна фурнітура, пластик, поліетилен, паралон, фетр, повсть, шнури, папір, джгут, фотоплівки, шкіра, метал, бісер, дріт тощо, дає незліченну варіативність фактур, текстур, форм ${ }^{33}$.

«Скіфія» демонструє роботи у 2D-, 3D-форматах. За принципами концептуалізму твори взаємодіють із простором, проникають у нього та губляться в ньому, подекуди балансують на межі з інтерактивним

\footnotetext{
${ }^{33}$ International textile art exhibition SCYTHIA. 2000 : catalog. Kherson, Ukraine, 2000.
} 
мистецтвом - перформансом. Не рідкість в експозиції інсталяції, об'єкти на перетині мистецтв.

Бієнале текстилю «Скіфія» - серед перших заходів на території України, що запропонували формат мінітекстилю як повноцінну тематичну норму. Кілька років куратори проводили саме такі заходи (2004, 2011, 2017 рр.). Було оголошено про обмеження за розміром: приймалися роботи, що не перевищували розмірів 30 х 30 см. Ідея спрацювала. Позитивними виявилися всі аспекти проєкту: суто технічний - менші роботи потребували менших виставкових площ, забезпечували полегшення монтажу; призначення заходу - у світовій експозиційній практиці мінітекстиль існує ще з 80-х рр., тож запровадити аналогічний напрям було досить влучною ідеєю; ефектність і видовищність - зменшення розміру ніяк не вплинуло на інтерактивність творів, їхню креативність, не завадило авторам експериментувати 3 матеріалами та технологіями. Однак такі епізоди в розвитку бієнале не мали глобального впливу та не стали постійним явищем і причиною переродження виставки. Тож організатори повернулися до початкових положень не ставити учасників в межі якихось умов, не змушувати майстрів розробляти твір під конкретну подію. Після 2004 р. ідея мінітекстилю зажила в Україні власним життям. 3'явилися ціла низка аналогічних заходів, але вже більш локального характеру. Уже щорічною стала виставка «Мінітекстиль» у Львові.

Цікавий прояв гендерних особливостей - бієнале «Скіфія» 2012 р. Звертаючись до актуальності суспільних питань статевої різниці, ідея авторів проєкту була показати окремо чоловічий погляд на мистецтво текстилю. Експозиція цього року вирізнялася більшою кількістю об'ємно-просторових композицій, інсталяцій, локальною та природною колірною гамою, але гендерний відбір жодним чином не позначився на ліричності та сентиментальності, душевності тематик.

Особливо масштабним i виразним став Міжнародний бієнале художнього текстилю «Скіфія» 2018 р. Саме цього року вперше виставка була проведена не на своїй батьківщині (м. Херсон), а в ІваноФранківську. Тут були представлені роботи учасників із багатьох країн, у різних техніках та 3 різноманітних матеріалів. Тематична розмаїтість створила особливе враження грандіозності. У ключі багатогранності сучасного мистецтва, тенденцій концептуалізму, абстракціонізму та попарту більшість робіт тяжіли до великих форм, умовності, безпредметності локальних плям, стимулювали глядача звертатися до глибин власних відчуттів. Нівелювання форми на поталу чуттєвості фактури, перепад форм для акцентування контрасту образів, межування текстур у напруженні мінливості світла та тіней - усе це виразні ознаки сучасного художнього текстилю як українських, так і закордонних майстрів. 
Автори не стримувалися в розмірах своїх творів, одні протистояли чіткій формі, інші підпорядковувалися ій, треті підкреслено порушували чи, навпаки, підсилювали. Створюється відчуття, що передує змінам, наче проєкт переростає, трансформується. Бієнале художнього текстилю, мабуть, найпотужніший міжнародний проєкт в Україні, спрямований саме на художній текстиль. В ідейному напрямі він наближається до світових тенденцій, що спрямовані на значно більш монументальний формат творів, які демонструє сьогодні Трієнале сучасного художнього текстилю в Лодзі. Величність і актуальність текстильних робіт, що експонуються в Лодзі, яскраво засвідчують, що текстиль як ланка сучасного мистецтва вже $є$ повноцінним учасником концептуального руху, є засобом досягнення ідеї, вираженням задуму митця, а не першочерговою метою чи майстерною ознакою.

Платформа бієнале текстилю пропагує творчість, фантазію в чистому їх вигляді, безкінечно дивує глядача та й самого майстра. Експонати однаково бентежать думки й тіло, припрошують комунікувати, взаємодіяти з ними, будять чуттєве, звертаються до свідомого та підсвідомого, порушують закони матеріального мистецтва. Досвід виставкових подій «Текстильний шал», «Текстилізм» дав розуміння діалогу глядача 3 митцем засобами текстилю. Ці проєкти орієнтовані лише на українського глядача, «Скіфія» ж намагається об’єднувати митців з усього світу, для інтерактиву та контакту, для обміну думками та досвідом, для співпраці, стираючи географічні межі. Великі мистецькі проєкти приводять до практичної співпраці митців, результатом $\epsilon$ спільні твори майстрів з іноді дуже віддалених одна від одної країн. У 2018 р. було виставлено декілька таких робіт, авторами були художники Литви й Уругваю, Литви та Туреччини тощо. За весь час існування бієнале в ньому взяли участь представники 68 країн світу: Великої Британії, Швеції, Франції, Данії, Японії, Кореї, Канади, Німеччини, Туреччини, Словаччини, Литви, Уругваю, Польщі, США, Білорусі й інших. Для України життя та розвиток Міжнародного бієнале художнього текстилю «Скіфія» $\epsilon$ чудовою можливістю сформувати власне ім'я на світовій мистецькій арені, привід закріпити за Херсоном честь «текстильного центру» України. «Скіфія» стабільно привертає увагу іноземних художників. Щоразу тут представляють 150-200 професійних робіт. Існує практика видавати каталоги 3 докладною інформацією про учасників і твори.

Можна вважати, що Міжнародний бієнале став своєрідним джерелом натхнення для кількох досить потужних всеукраїнських текстильних виставок, як-от: «Текстильний шал», «Мінітекстиль» (згадані вище), «Килим. Сучасні українські митці», «Трієнале художнього текстилю», “TEXTUS. Вишивка, текстиль, фемінізм», інші, менш масштабні 
проєкти $^{34}$. Кожен із них вирізняється наявністю певних меж, вужчими ідейними рамками, наявністю єдиної мети, тематичним спрямуванням чи іншими умовами, але деякою мірою це надає їм особливого звучання і яскравості. На даному етапі жоден проєкт не конкурує зі «Скіфією» і не презентується як міжнародна платформа.

3'являються заходи, пов'язані з художнім текстилем, спрямовані на науковий чи освітній процеси. Так, у Львові у 2007 р. проведено Науково-освітній міжнародний симпозіум «Архе-Нитка-Ново». Подія набула значного розголосу, однак залишилася разовою акцією, більше симпозіум не проводився. Ця громадська оказія стала джерелом інформації та натхнення, шкода, що ідея міжнародного наукового заходу не мала продовження.

Саме освітню мету мав Перший міжнародний симпозіум художнього текстилю «Вчитель і Учень», що відбувся у вересні 2017 р. у Львові. Захід був орієнтований переважно на студентів i викладачів. Учасниками були представники кількох країн Східної Свропи, а саме України, Польщі та Молдови ${ }^{35}$. Ця подія поєднала виставкову і науковоосвітню складові частини. У рамках програми відбулися групові i персональні виставки, студентська й окремо викладацька конференції. Незначна кількість країн-учасників зробила захід камерним і детальним. Хотілося б, щоб такі заходи набували більш значного поширення, однак, можливо, надалі зацікавлення буде лише зростати.

У контексті виставкових процесів України художній текстиль $\epsilon$ активним учасником загальномистецького руху. Однак 3 огляду на тенденції сучасного концептуального мистецтва текстильні твори лише на шляху до завоювання прихильності митців та глядачів. Текстиль лише починає проникати у виставкові зали концептуального мистецтва, залишаючись здебільшого відокремленим за принципом техніки та матеріалу.

\section{ВИСНОВКИ}

Художній текстиль пройшов еволюційний шлях від народного промислу, формувався в осередках, був показником національної ідентичності, мав окремі місцеві ознаки в умовах традиції. Водночас народне ткацьке ремісництво було проявом ідей та настроїв суспільства, втіленням побуту та затишку. Ремісниками було подолано шлях об'єднань та індустріалізації, формування артілей, виробництв і фабрик, переосмислення сталих, знакових мотивів, колірних відношень на

\footnotetext{
${ }^{34}$ Гончар К. Текстиль та contemporary art. Точки перетину. Художні практики початку XXI cm.: новаиії, тенденції, перспективи : матеріали Всеукраїнської науково-практичної конференції, м. Київ, 24 листопада 2017 р. Київ, 2017. С. 374.

35 Забашта Г. Перший міжнародний симпозіум художнього текстилю «Учитель і Учень» (Львів): уроки, висновки. Художні практики початку XXI ст.: новації, тенденції, перспективи : матеріали Всеукраїнської науково-практичної конфернції, м. Київ, 24 листопада 2017 р. Київ, 2017. С. 257-260.
} 
засадах продукування масової продукції. Утиснута в жорсткі рамки економіки та політичних постулатів творчість знайшла свій шлях вираження, продовжила свій розвиток у межах сучасного художнього текстилю.

Самобутність народного ткацького ремесла нині залишила за художнім текстилем потужне історичне підгрунтя й ознаки національної ідентифікації. Приналежність до декоративно-прикладного мистецтва збагатила художній текстиль варіативністю сформованих та відпрацьованих технік. Жорсткі умови промисловості Радянського Союзу заклали в художній текстиль основи умовності та лаконічності. Натомість можливості сучасності збагатили текстиль розмаїттям матеріалів, стимулювали його до експериментальності, а ідеї концептуалізму позбавили будь-яких обмежень.

Отже, сучасний художній текстиль формувався як самостійне явище та став засобом концептуального мистецтва, пройшов тернистий шлях трансформацій від традиційного народного промислу, через декоративно-ужиткове мистецтво та промисловий дизайн. Яскравою ілюстрацією цих тверджень $є$ діяльність українських митців, їхні здобутки в контексті світових тенденцій, активні виставкові проєкти.

\section{АНОТАЦІЯ}

Сутність висвітленої у статті проблеми полягає в розкритті історичних передумов для формування рис концептуалізму, що притаманні українському та світовому художньому текстилю. Завданням було з'ясування особливостей розвитку українського художнього текстилю на різних історичних етапах, характеристика сучасних процесів, персоналій і експозиційних рухів. Метою статті $є$ проведення умовного хронологічного аналізу розвитку художнього текстилю в Україні. За результатами встановлено взаємозв'язки народного ремісництва, декоративноужиткового мистецтва, виробничих процесів Радянського Союзу та принципів промислового дизайну із сучасним художнім текстилем. Виявлено вплив історичних трансформацій на форми вираження художнього текстилю. Охарактеризовано сутність українського текстильного мистецтва, визначено лінії перетину зі світовими нахилами творчості, окреслено переваги виставкової діяльності у сфері текстилю в Україні.

\section{ЛІТЕРАТУРА}

1. Андреева Е. Постмодернизм: Искусство второй половины XX начала XXI в. Санкт-Петербург : Азбука-классика, 2007. 493 с. 
2. Бажан О. Кролевець. Енцииклопедія історії України / редкол. : В. Смолій та ін. Інститут історії України НАН України. Київ : Наукова думка, 2009. Т. 5. С. 407-560.

3. Бажан О. Решетилівка. Енциклопедія історії України / редкол. : В. Смолій та ін. Інститут історії України НАН України. Київ : Наукова думка, 2012. Т. 9. С. 186-944.

4. Бобринская Е. Концептуализм. Москва : Галарт, 1994. 245 с.

5. Вербиленко Г. Косів. Енциклопедія історії України / редкол. : В. Смолій та ін. Інститут історії України НАН України. Київ : Наукова думка, 2009. Т. 5. С. 212-560.

6. Верменич Я. Дігтярі. Енциклопедія історї України / редкол. : В. Смолій та ін. Інститут історії України НАН України. Київ : Наукова думка, 2004. Т. 2. С. 399-518.

7. Гончар К. Текстиль та contemporary art. Точки перетину. Художні практики початку XXI ст.: новачії, тенденції, перспективи : матеріали Всеукраїнської науково-практичної конференції, м. Київ, 24 листопада 2017 р. Київ, 2017. С. 373-375.

8. Забашта Г. Перший міжнародний симпозіум художнього текстилю «учитель і учень» ( Львів): уроки, висновки. Художні практики початку XXI cm.: новації, тенденції, перспективи : матеріали Всеукраїнської науково-практичної конференції, м. Київ, 24 листопада 2017 р. Київ, 2017. C. 257-260.

9. Звінчук А. Художня практика художнього концептуалізму. Актуальні питання культурологї : альманах наукового товариства «Афіна». Рівне, 2012. Вип. 12. С. 3-6.

10. Кан Е. В начале было слово, и слово было “contemporary art". Apmкурсив. Інститут проблем сучасного мистецтва Національної академії мистецтв України. Київ, 2010. № 5. С. 13-16.

11. Кусько Г. Рух мистецтва тканини в Україні. Художній текстиль. Львівська школа : альбом / авт.-упоряд. Т. Печенюк. Львів, 1998. С. 78.

12. Кусько Г. Сучасний український текстиль: еволюція, досвід, перспективи. Студії мистецтвознавчі. Інститут мистецтвознавства, фольклористики та етнології ім. М.Т. Рильського Національної акдемії наук України. Київ, 2009. № 1(25), С. 113-117

13. Нечипоренко С. Декоративні тканини та килими України : альбомпосібник. Київ, 2005. 432 с.

14. Никорак О. Українська народна країна XIX-XX ст.: типологія, локалізація, художні особливості. Львів, 2004. 583 с.

15. Никорак О. Українська народна тканина XIX-XX ст.: типологія, локалізація, художні особливості. Інтер'єрні тканини (за матеріалами західних областей) : дис. ... докт. мистецвознавства: 17.00.06. Львів, 2007. $583 \mathrm{c}$. 
16. Селівачов М. Лексикон української орнаментики. Київ : редакція вісника «Ант», 2005. 400 с.

17. Сліпченко К. Коди «Трансформації» : стаття. Zaxid.net. 23.11.2017. URL: https://zaxid.net/kodi_transformatsiyi_n1442300.

18. Титова Е. Под сенью ангела : статья. Севастопольський художній музей ім. М.П. Крошицького : вебсайт. 03.07.2013. URL: http:// www.sevartmuseum.info/2013/07/podsenjuangelov.html.

19. Чегусова 3., Печенюк Т. Художній текстиль як складова національно-культурного простору (про Першу та Другу всеукраїнські трієнале художнього текстилю). Студї мистеизтвознавчі. Інститут мистецтвознавства, фольклористики та етнології ім. М.Т. Рильського Національної акдемії наук України. Київ, 2009. № 1 (25). С. 79-99.

20. Шевченко С. Українська народна тканина. Київ : Артанія, 1999. $416 \mathrm{c}$.

21. Шнайдер A. Конструктивні особливості об'єктів об'ємнопросторового текстилю. Наукові записки. Візуальні мистецтва. Серія «Мистеитвознавство». Тернопіль, 2017. № 1. Вип. 36. С. 190-197.

22. Яковець I. Художній текстиль ручного виготовлення: історичний контекст і значення у формуванні національної складової вітчизняної української культури. Збірник наукових праць Інституту мистецтвознавства, фольклористики та етнології ім. М.Т. Рильського Національної акдемії наук України. Київ, 2008. Вип. 8. С. 216-222.

23. Ямборко О. Килим у житловому інтер'єрі, як елемент радянської культури побуту. Народознавчі зошити. Львів, 2018. № 5 (143). C. $1149-1160$.

24. Ямборко О. Художник декоративного мистецтва i художня промисловість у радянській системі виробничих відносин. Наукові записки. Серія « Мистецтвознавство». Тернопіль, 2018. № 2. Вип. 39. C. $252-257$.

25. Ямборко О. Український тематичний килим 1930-1960-х рр. як мистецька практика соцреалізму. Народознавчі зошити. Львів, 2019. № 1 (145). С. 57-65.

26. Ямборко О. Українське промислове килимарство як бренд у радянській системі художніх промислів. Народознавчі зошити. Львів, 2020. № 1 (151). С. 49-59.

27. International textile art exhibition SCYTHIA. 2000 : catalog. Kherson. Ukraine, 2000.

28. Gunner Janice. Shibori. Batsford, 2006. 127 p.

29. Gunner Janice. Shibori for textile artists. Kodansha International, 2007. $127 \mathrm{p}$.

30. Ярослава Ткачук : інтерв'ю. Made in Ukraine. 12.10.2010. URL: http://made-in-ukraine.info/yaroslava-tkachuk/. 
31. Southan Mandy. Shibori: Designs and Technique. Search, 2008. 96 p. 32. Heppard Martha C.S. Wathercolor batik. An artist's guide to watercolor batik on rice paper. Xlibris Corporation, 2015. 84 p.

Information about author: Zhuravel-Zmieieva L. S., Postgraduate Student at the Department of Design and Technology Kyiv National University of Culture and Art 36, Yevgen Konovalets str., Kyiv, 01601, Ukraine 